ISSN 1392-3196 / e-ISSN 2335-8947

Zemdirbyste-Agriculture, vol. 103, No. 2 (2016), p. 229-238

DOI $10.13080 / \mathrm{z}-\mathrm{a} .2016 .103 .030$

\title{
Salt stress manifestation on plants, mechanism of salt tolerance and potassium role in alleviating it: a review
}

\author{
Hassan ABBASI ${ }^{1}$, Moazzam JAMIL ${ }^{1}$, Anwar $\mathrm{HAQ}^{2}$, Shafaqat $\mathrm{ALI}^{3}$, Rafiq AHMAD ${ }^{4}$, \\ Zafar MALIK $^{1}$, PARVEEN ${ }^{1}$ \\ ${ }^{1}$ University College of Agriculture and Environmental Sciences, \\ The Islamia University of Bahawalpur, Pakistan \\ E-mail: abbasiuaf@yahoo.com \\ ${ }^{2}$ Institute of Soil and Environmental Sciences, University of Agriculture \\ Faisalabad, Pakistan \\ ${ }^{3}$ Government College University \\ Faisalabad, Pakistan
}

${ }^{4}$ COMSATS Institute of Information Technology

Abbottabad, Pakistan

\begin{abstract}
Salinity is an agro-environmental problem limiting plant growth and development in the arid to semi-arid regions of the world and becomes the predicament of serious concern. Plants exposed to salt stress may undergo osmotic stress, ion toxicity and nutritional imbalance which results in production of reactive oxygen species (ROS). The ability of plants to detoxify radicals under conditions of salt stress is probably the most critical requirement and is determined by multifarious morpho-physiological and biochemical pathways like initial entry of salt to roots, intercellular compartmentation, synthesis of osmoprotectants (sugars, amino acids, proline and upgradation of antioxidant system) that results in maintaining ion homeostasis. This paper also revealed the plant responses to salinity stress with emphasis on physiological and biochemical mechanisms of salt tolerance which may help in interdisciplinary studies to assess the ecological consequence of salt stress. Moreover, the application of potassium helps the plants to cope with the hazardous effects of salinity by improving the morphological, physiological and biochemical attributes.
\end{abstract}

Key words: potassium, salinity, tolerance mechanism.

\section{Introduction}

Salinity is one of the most important abiotic stresses and a serious threat to agricultural sustainability. The extent of salinity problem is about $10 \%$ of world land area and $50 \%$ of irrigated areas which results in 12 billion US\$ loss of agricultural production (Flowers et al., 2010). The problem of salinity is further accelerated by converting fertile land of agriculture into other uses especially in urban areas which results in serious threats to fulfil $70 \%$ more production to meet the feeding of 9.3 billion population in 2050 (Shabala, 2013). Plant responses to salt stresses have been discussed over the last three decades (Yeo, Flowers, 1983; Zhu et al., 1998; Abbasi et al., 2012). Salt stress is a complex mechanism which affects almost every physiological and biochemical pathway in the plants (Cuartero et al., 2006; Nabati et al., 2011). Many morphological and physiological traits of plants are negatively affected by the soil salinity (Pitman, Lauchli, 2002; Parida, Das, 2005; Ahmad, 2010). The effects of salt stress are associated with low osmotic potential of soil solution resulting in water stress, nutritional imbalance, specific ion effect and any combination of these factors (Evelin et al., 2009). Salt stress may cause membrane disorganization, generation of toxic metabolites, inhibition of photosynthesis, generation of ROS and attenuated nutrient acquisition leading to cell and whole plant death (Hasegawa et al., 2000; Ashraf, 2004; Chartzoulakis, Psarras, 2005; Sun et al., 2011). Considerable progress in salinity tolerance has been made through conventional breeding methods (Ashraf, 2002). The selection for salt tolerance is more suitable and easy if plant species possess unique indicators in response to salinity stress (Ashraf, 2002; Munns, 2002). The complex mechanism of salt tolerance and high extent of variation at intra-specific and interspecific levels in plant constitute many difficulties to recognize a single indicator, which could be used as an effective selection criterion. Development of methods and strategies to ameliorate injurious effects of salt stress on 
plants has received considerable attention. But currently, there are no economically viable technological means to facilitate crop production under saline conditions (Ashraf, Foolad, 2007). Among various macro-nutrients, potassium $\left(\mathrm{K}^{+}\right)$occupies an important role in the survival of plants under salt stressed conditions (Mengel, Kirkby, 2001; Mahmood, 2011). A well balanced $\mathrm{K}^{+}: \mathrm{Na}^{+}$ ratio is crucial for the proper adjustment of stomatal function, activation of enzymes, protein synthesis, cell osmoregulation, oxidants metabolism, photosynthesis and turgor maintenance (Abbasi et al., 2014). In this review, much research information about the effects of salt stress on plant growth, plant responses to salinity and strategies to improve salt tolerance has been gathered with special emphasis on potassium role in alleviating salinity stress.

\section{Effects of salt stress on plant growth}

An injurious effect of salinity stress on plant growth can be classified into four factors.

Osmotic stress. The salt-induced osmotic stress is the major reason of growth reduction at initial stage of salt stress, while at later stages accumulation of $\mathrm{Na}^{+}$ occurs in the leaves and reduces plant growth (Munns, 2005; Munns, Tester, 2008; Rahnama et al., 2010). High concentration of salt in the root zone limits water potential of soil solution that strictly reduces plant root water conductivity. As a result, cell membrane permeability drops and influx of water to the plant is greatly reduced (Munns, 2002). In jute, relative water content, leaf water potential, water uptake, transpiration rate, water retention, and water use efficiency reduced under shortterm salt stress (Chaudhuri, Choudhuri, 1997). The plant species that are unable to regulate osmotically cannot maintain their turgor pressure which results in stomatal closure followed by reduced photosynthetic activity. Cell division and cell elongation was badly affected by loss in turgor pressure (Shannon et al., 1998). The different studies revealed that growth of the cells is primarily correlated with turgor potential and reduction in turgor pressure is one of the major causes of inhibition of plant growth under saline conditions, e.g., maize (Cramer et al., 1996), rice (Moons et al., 1995) and Shepherdia argentea (Qin et al., 2010).

Adverse effect of salinity in the form of osmotic stress at cellular level is well documented in a number of comprehensive reviews (Hasegawa et al., 2000; Munns, 2005; Munns, Tester, 2008). However, the extent of growth inhibition due to salt-induced osmotic stress depends on the type of plant tissue and concentration of salts present in growing medium (Munns et al., 2000). In view of the above mentioned reports it is clear that salinity causes osmotic stress to plants but the extent of the effect of this stress varies from species to species. It is therefore necessary to understand the physiological mechanisms responsible for the salinity tolerance, so as to find out whether their growth is limited by the saltinduced osmotic stress, or the toxic effect of the salt within the plant.
Specific ion toxicity. Plants take up and accumulate certain toxic ions from the irrigation water that restrict plant growth. It is different from salinity problem. It may occur even when the salinity is low. These toxic ions are sodium, chloride, sulphate and bicarbonates which are found in excessive amounts in most salt affected soils which can cause severe ion toxicity. However, plant responses to specific toxic ions differ and depend on the type of species (Dogan et al., 2010).

It is generally considered that excess amount of $\mathrm{Na}^{+}$causes nutrient imbalance, thereby causing specific ion toxicity (Ashraf, 1994). Salt sensitive species have no ability to control $\mathrm{Na}^{+}$transport. It has been observed that sodium ion appears to accumulate more rapidly to a toxic level than $\mathrm{Cl}^{-}$, therefore most studies have focused on $\mathrm{Na}^{+}$exclusion and the control of $\mathrm{Na}^{+}$transport within the plant (Munns, Tester, 2008). For example, salinity stress increased the levels of $\mathrm{Na}^{+}$and $\mathrm{Cl}^{-}$in all parts of guava, particularly in the leaves thereby resulting in growth reduction (Ferreira et al., 2001). Similarly, high accumulation of $\mathrm{Na}^{+}$in the leaves of different cultivars of Brassica napus reduces photosynthetic capacity (Ulfat et al., 2007). Qasim and Ashraf (2006) showed that differential salt tolerance in canola cultivars was due to low accumulation of $\mathrm{Na}^{+}$in their leaves. In view of a huge number of published reports Amtmann and Sanders (1999) were able to suggest that high $\mathrm{Na}^{+}$concentration in the cytoplasm interferes with normal ongoing metabolic processes. Consequently, plants try to avoid excessive accumulation of $\mathrm{Na}^{+}$in the cytoplasm.

Specific ion effect can further be assessed on salt sensitive and salt tolerant crop varieties. For example, leaf injuries and growth inhibition was observed in those cultivars that accumulate more $\mathrm{Na}^{+}$in their leaves, e.g., in radish, cabbage and canola (Jamil et al., 2007). In addition to $\mathrm{Na}^{+}$being a toxic ion, in some species, such as soybean, citrus and grapevine, $\mathrm{Cl}^{-}$is considered to be the more toxic ion (Grattan, Grieve, 1999). Physiological basis of $\mathrm{Cl}^{-}$toxicity on plant growth can be explained in view of the arguments of White and Broadley (2001) that chloride $\left(\mathrm{Cl}^{-}\right)$is taken up through roots and transported to shoot where it causes damaging effects on photosynthesis and other metabolic processes. From these reports, it can be concluded that excessive amounts of cations or anions in growth medium can cause ion toxicity which is genotype-specific. However, variation in specific ion toxicity at inter-specific or intra-specific level could be due to some adaptations to toxic ions, which is speciesspecific.

Nutritional imbalance. It is now well established that the interactions between salts and mineral nutrients result in considerable nutrient instability (Azeem, Ahmad, 2011). Ionic imbalance occurs in the cells due to excessive accumulation of $\mathrm{Na}^{+}$and $\mathrm{Cl}^{-}$and reduces the uptake of other mineral nutrients, such as $\mathrm{K}^{+}, \mathrm{Ca}^{2+}$ and $\mathrm{Mn}^{2+}$ (Karimi et al., 2005). At higher level, salinity limits the concentration of $\mathrm{K}^{+}$and $\mathrm{Ca}^{2+}$ in the leaves and roots of Brassica napus (canola) cultivars (Ulfat et al., 2007; Ashraf, Ali, 2008). High $\mathrm{Na}^{+}: \mathrm{K}^{+}$ratio adversely affects metabolic processes in plants (Dogan et al., 2010). 
High concentration of $\mathrm{Na}^{+}$and $\mathrm{Cl}^{-}$ions in soil solution reduced the uptake of $\mathrm{K}^{+}$ions which ultimately caused $\mathrm{K}^{+}$deficiency in plants. $\mathrm{K}^{+}$deficiency results in chlorosis and then necrosis in plant leaves (Gopal, Dube, 2003). Potassium is very important for enzymes activation, protein synthesis, osmoregulation, stimulating photosynthesis and maintaining cell turgor pressure (Freitas et al., 2001; Ashraf, 2004). $\mathrm{Ca}^{2+}$ and $\mathrm{K}^{+}$both are very important for maintaining proper functioning and reliability of cell membranes (Wenxue et al., 2003). Maintenance of required $\mathrm{K}^{+}$level in plant cell under saline conditions depends upon selective uptake of $\mathrm{K}^{+}$, cellular compartmentation of $\mathrm{Na}^{+}$and $\mathrm{K}^{+}$and distribution in the leaf tissues (Carden et al., 2003). Maintenance of the adequate level of calcium and its transport in plant cells under salinity stress is also very important parameters for measuring salinity tolerance (Soussi et al., 2001; Unno et al., 2002).

Moreover, numerous studies have revealed that salt stress can reduce $\mathrm{K}^{+}, \mathrm{Ca}^{2+}$ and $\mathrm{N}$ accumulation in different crop plants, e.g., wheat (Raza et al., 2006), sunflower (Akram et al., 2007), radish, cabbage (Jamil et al., 2007) and canola (Ulfat et al., 2007). Salinity reduces nutrient availability as well as transport to the growing regions of the plant, thereby affecting the quality of both vegetative and reproductive organs. For example, higher concentrations of $\mathrm{Na}^{+}$in soil decreased the $\mathrm{Ca}^{2+}$ activity in the external medium which also results in less availability of $\mathrm{Ca}^{2+}$ in Celosia argentea (Carter et al., 2005).

In view of these reports, it is quite clear that salt stress limits the accumulation of essential nutrients such as $\mathrm{K}^{+}, \mathrm{Mg}^{2+}$ and $\mathrm{Ca}^{2+}$ while increases the concentration of $\mathrm{Na}^{+}$in most crop species thereby resulting in reduced growth and yield. This argument is further supported by a number of studies in which it was found that exogenous application of salt-induced deficient nutrient such as $\mathrm{Ca}, \mathrm{K}$ or $\mathrm{N}$ can mitigate the adverse effects of salinity on growth of many crops, e.g., wheat, sunflower and beans, etc. (Shabala et al., 2006; Akram et al., 2007; Mahmood, 2011).

Reactive oxygen species. Plants exposure to salt stress enhanced the production of reactive oxygen species (ROS) such as $\mathrm{H}_{2} \mathrm{O}_{2}$ (hydrogen peroxide), $\mathrm{O}_{2}^{-}$(superoxide), ${ }^{1} \mathrm{O}_{2}$ (singlet oxygen) and $\mathrm{OH}^{-}$(hydroxyl radical). Overproduction of ROS enhanced lipid peroxidation, protein degradation and DNA mutation (Pitzschke et al., 2006). In plant cells, ROS mainly $\mathrm{H}_{2} \mathrm{O}_{2}, \mathrm{O}_{2}^{-}$and a hydroxyl ion $\mathrm{OH}^{-}$are generated in the cytosol, chloroplasts, mitochondria and the apoplastic space (Mittler, 2002; Abbasi et al., 2014). A rise in ROS production may result in membrane injury (Shalata et al., 2001).

Plants have developed antioxidant defense system to detoxify the ROS, which includes nonenzymatic antioxidant compounds (tocopherols and carotenoids) and enzymatic antioxidant like superoxide dismutase (SOD), catalase (CAT), peroxidase (POD) (Ali et al., 2011; Abbasi et al., 2014). For instance, in a series of experiments with pea (Pisum sativum) plants, Hernandez et al. (1995) reported that a salt tolerant pea cultivar had higher activities of mitochondrial Mn-SOD, chloroplastic $\mathrm{CuZn}$-SOD and ascorbate peroxidase than those in a salt sensitive pea cultivar. Similarly, overproduction of glutathione reductase (GSH) and ascorbate peroxidase (APX) have been shown to improve oxidative stress tolerance, resulting in enhanced water stress in wheat (Sairam et al., 1998). While working with cowpea (Vigna radiata L.), Cavalcanti et al. (2004) concluded that efficient SOD-APX-CAT antioxidant system is not necessarily involved in enhancing salinity tolerance in plants. Kholova et al. (2010) reported that salt tolerant maize genotypes have high activites of SOD, APX, CAT, glutathione reductase (GR) and comparatively lower $\mathrm{O}_{2}^{-}$, $\mathrm{H}_{2} \mathrm{O}_{2}$ and thiobarbituric acid reactive substance contents compared to salt sensitive maize genotypes under different salinity levels.

Concluding from all these reports, we can suggest that increase in antioxidant enzymes is a part of the mechanism of salt tolerance and scavenging of ROS through any enzymatic or non-enzymatic antioxidants is more important than simply higher activities of antioxidants. However, although a wide range of genetic adaptations to saline conditions have been observed in a number of crop species, underlying mechanisms of oxidative stress tolerance in crop plants are still not completely understood and thus further research should be done.

\section{Strategies to improve salt tolerance}

Intra-cellular compartmentation. It has been reported that numerous mechanisms are involved in salinity tolerance of plants at cell level.

Ion homeostasis pathway. The potassium homeostasis in cytoplasm plays central role in cell metabolism and normal functioning. Different studies have depicted the dramatic decline in potassium concentration under salinity stress (Abbasi et al., 2014; 2015 a) along with strong positive association of shoot $\mathrm{K}^{+}$concentration and plant for salt tolerance (Chen et al., 2005). Moreover, ability of roots to retain more potassium has also been verified as one of the key factors deliberating the salt tolerance in wheat (Cuin et al., 2011), maize (Abbasi et al., 2014), barley (Chen et al., 2005; 2007), bean (Dawood et al., 2014) and lucerne (Smethurst et al., 2008). The application of potassium fertilizers under saline conditions has results in improvement of plant growth (Abbasi et al., 2015 b).

The potassium is a key nutrient which contributes about $35 \%$ to $50 \%$ of cell osmotic potential (Rivelli et al., 2002). Different halophytic species own better ability to retain more potassium under saline conditions (Garthwaite et al., 2005). Plant ability to maintain higher $\mathrm{K}^{+}: \mathrm{Na}^{+}$ratio is also a key feature for salt tolerance of plants (Shabala, Cuin, 2008; Abbasi et al., 2015 b). $\mathrm{K}^{+}: \mathrm{Na}^{+}$judgment has been subjected to quantitative trait loci (QTL) analysis for salinity tolerance in various experiments (Lindsay et al., 2004). Different features explain this essentiality, e.g., both $\mathrm{K}^{+}$and $\mathrm{Na}^{+}$compete for binding sites due to 
similarities in valences (Bortner, Cidlowski, 2007). Two main findings support this concept: $1^{\text {st }}$ - presence of CED9 gene retains more potassium and improves salinity tolerance in tobacco (Shabala et al., 2007); $2^{\text {nd }}$ - activity of caspase-like proteases and endonucleases under saline stress conditions retain more $\mathrm{K}^{+}$in the cytosol (Demidchik et al., 2010). It suggests that cytosolic $\mathrm{K}^{+}: \mathrm{Na}^{+}$ratio is not only the important feature but also high concentration of $\mathrm{K}^{+}$is necessary to deliberate salt tolerance.

The production of ROS is significantly increased under salinity stress both in roots and shoots of plant but application of potassium under saline conditions detoxifies the harmful effect of ROS by improving photosynthetic electron transport (Marschner, Cakmak, 1989; Cakmak, 2005). Other important aspects are the involvement of tonoplast NHX exchangers which are $\mathrm{Na}^{+}: \mathrm{H}^{+}$antiporters that help to maintain potassium homeostasis under saline environment (Apse et al., 1999). These NHX genes improve the salt tolerance of plants (Zhang, Blumwald, 2001).

$\mathrm{Na}^{+}$is pumped into vacuole which enters into leaf cells before it approaches toxic level for various enzymatic activities. A vacuolar $\mathrm{Na}^{+}: \mathrm{H}^{+}$antiporter controls this activity (Blumwald et al., 2000). The $\mathrm{Na}^{+}: \mathrm{H}^{+}$antiporters activity is induced by the addition of salt but its enhancement is more in salt tolerant than salt sensitive species (Staal et al., 1991). Certain experiments have placed emphasis on the mechanism where over expressing of vacuolar transporter has improved salinity tolerance of tomato and rice (Zhang, Blumwald, 2001; Fukuda et al., 2004). The storage of $\mathrm{Na}^{+}$is facilitated and enhanced by the increased uptake of $\mathrm{Na}^{+}$to short vacuoles and eventually conferring high tolerance by lessening $\mathrm{Na}^{+}$in cytosol.

Synthesis of osmoprotectants. During osmotic stress, plants accumulate specific organic solutes such as proline, free amino acids, sugars and quaternary ammonium compounds which are called as compatible solutes. These chemicals do not interfere with plant enzymatic activities even when present in higher concentration (Ashrafijou et al., 2010; Nabati et al., 2011). These chemicals are present in cytoplasm and certain ions such as $\mathrm{Na}^{+}$and $\mathrm{Cl}^{-}$are preferentially sequestered into vacuole which leads to help in turgor maintenance during osmotic stress (Bohnert et al., 1995).

Sugars. Soluble sugars play a central role in osmotic adjustment in almost all plants under salinity stress conditions. Many researchers reported that under drought or salinity stress, plants accumulate sucrose (Nabati et al., 2011). Other soluble sugars such as fructose and glucose are also very important and have significant role under stress conditions. Ashraf and Naqvi (1992) reported that under salinity stress soluble sugars in shoots of four Brassica species such as B. carinata, B. juncea, B. campestris and B. napus were increased, except $B$. carinata. When we applied salt in the plant growth medium, it markedly decreased the total sugar contents in the leaves of all eight cultivars of canola except the line 'Oscar' (Qasim, 2000).

Free amino acids. Under salinity stress, free amino acids also play major role as a solute in osmotic adjustment of plants (Ashrafijou et al., 2010). Previously it was considered that osmotic adjustment does not give the physiological basis for this parameter in salinity tolerance (Munns, 1993). But identification of solutes in the cells under salinity stress could prove valuable information in identifying the plants which are more salt-tolerant. The several amino acids such as arginine, glycine, alanine, serine, valine, leucine and proline, take part in osmotic adjustment of cell (Mansour, 2000). By increasing salt dose in the growth medium, total free amino acids were markedly increased in all eight cultivars under observation of canola lines (Qasim, 2000).

Proline. Generally, in higher plants proline contents are higher and its contents further enhanced under salinity stress (Dogan et al., 2010; Nabati et al., 2011). It is a well known fact that proline plays vital role in membrane stabilization in plant cells (Gadallah, 1999). The proline production has been narrated as a non specific response of plants under water stress condition (Ashraf, 1994). It was reported that proline contents were increased markedly in four Brassica species such as B. juncea, B. campestris, B. napus and B. carinata under salinity stress by increasing in $\mathrm{Na}^{+}: \mathrm{Ca}^{2+}$ ratio of the growth solution (Ashraf, Naqvi, 1992). It was observed that salt tolerant cultivars of $B$. juncea accumulate markedly higher concentration of proline in leaves than salt-sensitive cultivars under salinity stress (Kumar, 1984). In B. juncea, it was observed that proline played a significant role in decreasing lipid peroxidation (Alia et al., 1993).

Shot-gun approaches. To induce salt tolerance in plants, scientists proposed exogenous applications of compatible solutes, antioxidants, growth promoters, and inorganic salts (Hayat, Ahmad, 2003; Raza et al., 2006; Ashraf, Foolad, 2007; Abbasi et al., 2014). Although, a number of traditional plant breeding, molecular biology and genetic engineering techniques are trying to develop salt tolerant lines/cultivars of important commercial crops but a limited success has been achieved in developing salttolerant cultivars through them (Ashraf, Foolad, 2007; Abbasi et al., 2014). Alternatively, some salt resistant varieties have been developed by exogenous application of various inorganic and organic chemicals. Exogenous application of these compounds has been proposed as an efficient and cost effective approach to improve crop productivity under stress conditions (Ashraf, Foolad, 2007; Abbasi et al., 2014).

\section{Effect of potassium on morphological, physiological and biochemical attributes}

Morphological attributes. Salinity is an agroenvironmental problem limiting plant growth and development in the arid and semi-arid regions of the world (Ashraf, 2004). Salinity stress reduces relative growth rate, net photosynthetic rate, net assimilation rate and alters biomass production (Akram et al., 2011; Sun 
et al., 2011). Kabir et al. (2004) reported that salinity reduced total dry matter of plants which ultimately caused reduction in crop yield but application of potassium improved growth and biomass yield of barley and bean under saline conditions (Mahmood, 2011; Dawood et al., 2014). Potassium was applied at the rates of $0,40,80$ and $120 \mathrm{~kg} \mathrm{ha}^{-1}$. Maximum grain yield and 1,000-grain weight was obtained by applying potassium at $120 \mathrm{~kg} \mathrm{ha}^{-1}$ (Sharif, Hussain, 1993).

The inhibitory effect of salinity on potassium translocation was stronger with low potassium concentration in the nutrient solution, when compared at two levels of $\mathrm{K}^{+}$supply in maize seedlings, i.e. 0.1 and $1 \mathrm{mmol} \mathrm{L}^{-1}$ (Botella et al., 1997). Thereby, salinity did not affect root dry weight, but low levels of $\mathrm{K}^{+}$in the nutrient solution significantly reduced shoot dry weight. Yield components in maize like ear length, 1,000-grain weight and number of grains per ear remained unaffected but yield per ear was significantly affected by increasing potash rate. Similarly, the parameters like plant height, days to tasseling and silking remained unaffected, however stalk yield and protein contents were significantly affected. Similar responses have been found in spinach plants, which responded to an increasing $\mathrm{K}^{+}$concentration, reducing the differences in shoot growth between plants grown under low salinity and those grown under high salinity (Chow et al., 1990). The salinity-induced inhibition of shoot growth at low levels of $\mathrm{K}^{+}$in the root medium was attributed to the effect of $\mathrm{K}^{+}$deficiency and/ or $\mathrm{Na}^{+}$toxicity on the plants. The most recommended level of potassium is $125-160 \mathrm{~kg} \mathrm{ha}^{-1}$ beyond this the application of potassium is not profitable (Chaudhry, Malik, 2000). Applying potassium at a rate of $150 \mathrm{~kg} \mathrm{ha}^{-1}$ increased grain yield by $10.8 \mathrm{~kg}$ for each $\mathrm{kg}$ potassium applied and net profit (Zhang et al., 2000).

Physiological attributes. Potassium is essential for many physiological attributes like photosynthesis, activation of enzymes and reducing excess uptake of sodium under saline and drought conditions (Mengel, Kirkby, 2001; Reddy et al., 2004). Potassium is an important nutrient that maintains the turgidity in plant cells (Carroll et al., 1994). Salinity reduced adversely the relative water contents and water retaining capacity but application of higher amount of potassium significantly improved the plant water relation in mungbean plant (Kabir et al., 2004). High salinity caused a great reduction in growth such as leaf area, fresh and dry weight of leaves. These changes were related to a decrease in relative water content and $\mathrm{K}^{+}$concentration (Ghoulam et al., 2002). The decreased relative water content (RWC) under saline conditions was also reported in different crops, including alfalfa (Serraj, Drevon, 1998), mungbean (Nandwal et al., 2000) and burning bush (Kochia scoparia) (Nabati et al., 2011).

Effect of potassium on photosynthesis efficiency has been observed in sugarcane and it was noticed that salinity treatment significantly reduced photosynthetic efficiency but application of potassium significantly improved photosynthetic parameters (Noaman, 2004). The higher rates of photosynthesis were attributed to lower concentration of $\mathrm{Na}^{+}$and $\mathrm{Cl}^{-}$in the leaves (Dogan et al., 2010; Abbasi et al., 2015 a). Perera et al. (1994) reported that transpiration and stomatal conductance decreased with salinity. Transpiration and stomatal conductance are directly involved in photosynthesis, decrease in transpiration and stomatal conductance results in the decrease in $\mathrm{CO}_{2}$ assimilation and photosynthesis. They further concluded that higher stomatal conductance in plants is known to increase $\mathrm{CO}_{2}$ diffusion into leaf, thereby favouring higher photosynthetic rates. Higher $\mathrm{CO}_{2}$ assimilation rates could in turn favour a high growth and higher crop yield. Leaf growth, gas exchange and chlorophyll fluorescence of the sorghum varieties were measured in response to $\mathrm{NaCl}$ concentration by Netondo et al. (2004). Meloni et al. (2004) also studied the effect of salinity on some growth and physiological parameters in algarrobo (Prosopis alba L.) seedling and concluded that high salinity reduced root growth, shoot growth and relative water contents.

Biochemical attributes. Salinity reduces plant growth by inhibiting many physiological and biochemical processes such as nutrient uptake and assimilation (Munns, 2002; Ali et al., 2011). Potassium is essential for protein synthesis, activation of enzymes and photosynthesis; osmoticum mediating cell expansion and turgor driven movements and competitor of $\mathrm{Na}^{+}$under salt stress $(\mathrm{Hu}$, Schmidhalter, 2005). Several studies have shown that application of potassium mitigates the unfavourable effects of salinity through its role in stomatal regulation, osmoregulation, energy status, charge balance, protein synthesis and homeostasis (Sanjakkara et al., 2001; Mahmood, 2011).

Potassium in elemental form is generally required to activate at least 60 different enzymes which take part in plant growth (Suelter, 1985). Enzymes are proteins in nature and synthesis of proteins depends on the efficient nitrogen metabolism which is disturbed by salinity. Transport of amino acids to the sites of protein synthesis and balancing of electrical charges are among key roles of potassium (Ashraf, 2004). Potassium is often considered to be a nutrient of primary importance for cereal and oil seed crops. Plants exposed to environmental stress factors, such as salinity, drought, high light intensity and nutrient limitations, suffer from oxidative damage catalyzed by reactive oxygen species (ROS), e.g., super oxide, hydrogen peroxide and hydroxyl radical, ion toxicity and K-deficiency. Salt tolerant genotypes respond to salinity by increasing anti-oxidative defense systems for detoxification of ROS (Zhu, 2001; Ali et al., 2011; Sun et al., 2011).

Increasing evidence suggests that improvement of potassium $\left(\mathrm{K}^{+}\right)$nutritional status of plants can greatly lower the ROS production (Cakmak, 2005; Abbasi et al., 2014). Potassium humate application increased the activities of superoxide dismutase (SOD), peroxidases (POD) and catalase (CAT), decreased the content of MDA and delayed the senescence of ginger roots (Liang et al., 2007). $\mathrm{KNO}_{3}$ application alleviates salinity effect in winter wheat by enhancing activities of antioxidant enzymes (Zheng et al., 2008). The scavenging of ROS by the scavenging system especially SOD, CAT and GPX activities was improved by potassium application (Soleimanzadeh et al., 2010; Abbasi et al., 2014). 
Suelter (1985) has reported that application of potassium accelerates the enzymatic activity of pyruvate kinase involved in conversion of 3-p-glyceraldehyde to pyruvate with associated energy production in the glycolytic pathway. For maintaining ionic balance in the vacuole, cytoplasm accumulates low molecular weight compound which are termed as compatible solutes. These compatible solutes included mainly proline (Singh et al., 2000) and glycinebetain (Khan et al., 1998). They do not interfere with normal biochemical function of plants.

Accumulation of $\mathrm{Na}^{+}$and impairment of potassium nutrition is major characteristic of saltstressed plants. Therefore, $\mathrm{K}^{+}: \mathrm{Na}^{+}$ratio in plants is considered a useful guide to assess salt tolerance (Akram et al., 2010; Abbasi et al., 2015 b). Selection or breeding genotypes with high $\mathrm{K}^{+}: \mathrm{Na}^{+}$ratio is an important strategy to minimize growth deceases in saline soils (SantaMaria, Epstein, 2001). Rascio et al. (2001) identified a wheat mutant with a high ability to accumulate $\mathrm{K}^{+}$in the shoot and showed that this mutant compared to other wheat genotypes greatly improved tissue hydration, seed germination and seedling growth under increasing concentration of $\mathrm{NaCl}$. Saline soils generally have higher concentrations of $\mathrm{Na}^{+}$than $\mathrm{K}^{+}$and $\mathrm{Ca}^{2+}$ which may result in passive accumulation of $\mathrm{Na}^{+}$in root and shoot (Bohra, Doerffling, 1993). High levels of $\mathrm{Na}^{+}$can displace $\mathrm{Ca}^{2+}$ from root membranes, changing their integrity and thus affecting the selectivity for $\mathrm{K}^{+}$uptake (Cramer et al., 1996). Xylem loading of $\mathrm{K}^{+}$is regulated by $\mathrm{K}^{+}$uptake from external solution (Engels, Marschner, 1992). This indicates that $\mathrm{Na}^{+}$salinity besides reducing the $\mathrm{K}^{+}$uptake rate also interferes to a greater extent in $\mathrm{K}^{+}$translocation from root to shoot, which results in a lower $\mathrm{K}^{+}$shoot content and a higher $\mathrm{K}^{+}$root content.

\section{Future prospects}

Salinity effects and problems with a view of tolerance and ecological performance are discussed briefly in this review. Attempts have been made to compare the relative sensitivity of miscellaneous plant species to salt uptake and transport of $\mathrm{NaCl}$ with regard to phytotoxicity and their interactions with nutrients. Improving potassium nutritional status of plants greatly minimizes detrimental effects of salinity which appears to be related to the inhibitory role of potassium against reactive oxygen species (ROS) production. So, the molecular factors that can be used for genetic engineering of salt-tolerant plants include over-expression of specific transcription factors, characterization of dehydrin proteins, overproduction of osmoprotectants, expression of water channel proteins and ion transporters and expression and characterization of genes which are involved in uptake and transport of potassium under salt stress conditions should be studied to tackle the problem of salinity in more effective way.

\section{Acknowledgments}

Authors highly acknowledge funding from the Higher Education Commission (HEC), Islamabad for providing the funds.

Received 11022016

Accepted 11042016

\section{References}

1. Abbasi G. H., Akhtar J., Haq M. A., Ahmad N. 2012. Screening of maize hybrids for salt tolerance at seedling stage under hydroponic condition. Soil and Environment, 31: 83-90.

2. Abbasi G. H., Akhtar J., Haq M. A., Ali S., Chen Z. H., Malik W. 2014. Exogenous potassium differentially mitigates salt stress in tolerant and sensitive maize hybrids. Pakistan Journal of Botany, 46: 135-46.

3. Abbasi G. H, Akhtar J., Haq M. A., Malik W., Ali S., Chen Z. H., Zhang G. 2015 (a). Morpho-physiological and micrographic characterization of maize hybrids under $\mathrm{NaCl}$ and $\mathrm{Cd}$ stress. Plant Growth Regulation, 75: 115-122 http://dx.doi.org/10.1007/s10725-014-9936-6.

4. Abbasi G. H., Akhtar J., Ahmad R., Jamil M., Haq M. A., Ali S., Ijaz M. 2015 (b). Potassium application mitigates salt stress differentially at different growth stages in tolerant and sensitive maize hybrids. Plant Growth Regulation. 76: 111-125

http://dx.doi.org/10.1007/s10725-015-0050-1.

5. Ahmad B. 2010. Effect of salinity and $\mathrm{N}$ sources on the activity of antioxidant enzymes in canola (Brassica napus L.). Journal of Food Agricultural Environment, 8: 350-353.

6. Akram M. S., Athar H. U. R., Ashraf M. 2007. Improving growth and yield of sunflower (Helianthus annuus L.) by foliar application of potassium hydroxide $(\mathrm{KOH})$ under salt stress. Pakistan Journal of Botany, 39: 769-776.

7. Akram M., Ashraf M. Y., Ahmad R., Waraich E. A., Iqbal J., Mohsan M. 2010. Screening for salt tolerance in maize (Zea mays L.) hybrids at an early seedling stage. Pakistan Journal of Botany, 42: 141-154.

8. Akram M., Afzal M., Ashraf M. 2011. Detecting differences in some elite wheat lines for salt tolerance through multi parameters evaluation i.e. morphological and yield parameters. Pakistan Journal of Botany, 43 (1): 435-443.

9. Ali S., Zeng F., Cai S., Qiu B., Zhang G. 2011. The interaction of salinity and chromium in the influence of barley growth and oxidative stress. Plant, Soil and Environment, 57: 153-159.

10. Alia P., Sardhi P., Mohanty P. 1993. Proline in relation to free radical production in seedlings of Brassica juncea raised under sodium chloride stress. Plant and Soil, 156: 497-500

http://dx.doi.org/10.1007/BF00025092.

11. Amtmann A., Sanders D. 1999. Mechanisms of $\mathrm{Na}^{+}$ uptake by plant cells. Advances in Botanical Research, 29: $75-112$

http://dx.doi.org/10.1016/S0065-2296(08)60310-9.

12. Apse M. P., Aharon G. S., Snedden W. A., Blumwald E. 1999. Salt tolerance conferred by overexpression of a vacuolar $\mathrm{Na}^{+} / \mathrm{H}^{+}$antiport in Arabidopsis. Science, 285: $1256-1258$

http://dx.doi.org/10.1126/science.285.5431.1256.

13. Ashraf M. 1994. Breeding for salinity tolerance in plants. Critical Reviews in Plant Sciences, 13: 17-42 http://dx.doi.org/10.1080/713608051.

14. Ashraf M. 2002. Salt tolerance of cotton. Some new advances. Critical Reviews in Plant Sciences. 21: 1-30 http://dx.doi.org/10.1016/S0735-2689(02)80036-3.

15. Ashraf M. 2004. Some important physiological selection criteria for salt tolerance in plants. Flora, 199: 361-76 http://dx.doi.org/10.1078/0367-2530-00165.

16. Ashraf M., Naqvi M. I. 1992. Effect of varying Na/ $\mathrm{Ca}$ ratios in saline sand culture on some physiological parameters of four Brassica species. Acta Physiologiae Plantarum, 14: 197-205.

17. Ashraf M., Foolad M. A. 2007. Improving plant abiotic-stress resistance by exogenous application of osmoprotectants glycine betaine and proline. Environmental and Experimental Botany. 59: 206-216 http://dx.doi.org/10.1016/j.envexpbot.2005.12.006. 
18. Ashraf M., Ali Q. 2008. Relative membrane permeability and activities of some antioxidant enzymes as the key determinants of salt tolerance in canola (Brassica napus L.). Environmental and Experimental Botany, 63: 266-273 http://dx.doi.org/10.1016/j.envexpbot.2007.11.008.

19. Ashrafijou M., Noori S. A. S., Darbandi A. I., Saghafi S. 2010. Effect of salinity and radiation on proline accumulation in seeds of canola (Brassica napus L.). Plant, Soil and Environment, 56: 312-317.

20. Azeem M., Ahmad R. 2011. Foliar application of some essential minerals on tomato (Lycopersicon esculentum) plant grown under two different salinity regimes. Pakistan Journal of Botany, 43: 1513-1520.

21. Blumwald E., Aharon G. S., Apse M. P. 2000. Sodium transport in plant cells. Biochimica et Biophysica Acta Biomembranes, 1465 (1-2): 140-151.

22. Bohnert H. J., Nelson D. E., Jensen R. G. 1995. Adaptations to environmental stresses. Plant and Cell, 7: 1099-1111 http://dx.doi.org/10.1105/tpc.7.7.1099.

23. Bohra J. S., Doerffling K. 1993. Potassium nutrition of rice (Oryza sativa $\mathrm{L}$.) varieties under $\mathrm{NaCl}$ salinity. Plant and Soil. 152 (2): 299-303 http://dx.doi.org/10.1007/BF00029100.

24. Bortner C. D., Cidlowski J. A. 2007. Cell shrinkage and monovalent cation fluxes: role in apoptosis. Archives of Biochemistry and Biophysics. 462: 176-188 http://dx.doi.org/10.1016/j.abb.2007.01.020.

25. Botella M. A., Martinez V., Pardines J. 1997. Salinity induced potassium deficiency in maize plants. Journal of Plant Physiology, 150: 200-205 http://dx.doi.org/10.1016/S0176-1617(97)80203-9.

26. Cakmak I. 2005. The role of potassium in alleviating detrimental effects of abiotic stresses in plants. Journal of Plant Nutrition and Soil Science. 168: 521-530 http://dx.doi.org/10.1002/jpln.200420485.

27. Carden D. E., Walker D. J., Flowers T. J., Miller A. J. 2003. Single-cell measurements of the contributions of cytosolic $\mathrm{Na}^{+}$and $\mathrm{K}^{+}$to salt tolerance. Plant Physiology, 131: 676-683 http://dx.doi.org/10.1104/pp.011445.

28. Carroll M. J., Slaughter L. M., Krouse J. M. 1994. Turgor potential and osmotic constituents of kentucky blue grass leaves supplied with four levels of potassium. Agronomy Journal, 86: 1079-1083 http://dx.doi.org/10.2134/agronj1 994.00021962008600060028x.

29. Carter C. T., Grieve C. M., Poss J. A. 2005. Salinity effects on emergence, survival, and ion accumulation of Limonium perezii. Journal of Plant Nutrition. 28: 1243-1257 http://dx.doi.org/10.1081/PLN-200063293.

30. Cavalcanti F. R., Oliveira J. T. A., Martins-Miranda A. S., Viegas R. A., Silveira J. A. G. 2004. Superoxide dismutase, catalase and peroxidase activities do not confer protection against oxidative damage in salt-stressed cowpea leaves. New Phytologist. 163 (3): 563-571 http://dx.doi.org/10.1111/j.1469-8137.2004.01139.x.

31. Chartzoulakis K., Psarras G. 2005. Global change effect on crop photosynthesis and production in Mediterranean: the case of Crete, Greece. Agriculture, Ecosystems and Environment, 106: 147-157 http://dx.doi.org/10.1016/j.agee.2004.10.004.

32. Chaudhry A., Malik J. K. 2000. Determination of optimum level of potash and its effect on yield and quality of maize. Pakistan Journal of Biological Science, 3: 75-80.

33. Chaudhuri K., Choudhuri M. A. 1997. Effects of shortterm $\mathrm{NaCl}$ stress on water relations and gas exchange of two iute species. Biologia Plantarum. 40 (3): 373-380 http://dx.doi.org/10.1023/A:1001013913773.

34. Chen Z., Newman I., Zhou M., Mendham N., Zhang G., Shabala S. 2005. Screening plants for salt tolerance by measuring $\mathrm{K}^{+}$flux: a case study for barley. Plant Cell and Environment, 28: 1230-1246 http://dx.doi.org/10.1111/j.1365-3040.2005.01364.x.
35. Chen Z., Zhou M., Newman I., Mendham N., Zhang G., Shabala S. 2007. Potassium and sodium relations in salinised barley tissues as a basis of differential salt tolerance. Functional Plant Biology, 34: 150-162 http://dx.doi.org/10.1071/FP06237.

36. Chow W. S., Marylin C. B., Anderson J. M. 1990. Growth and photosynthetic responses of spinach to salinity: Implications of $\mathrm{K}^{+}$nutrition for salt tolerance. Australian Journal of Plant Physiology, 17: 563-578 http://dx.doi.org/10.1071/PP9900563.

37. Cramer G. R., Alberico G. J., Schmidt C. 1996. Salt tolerance is not associated with the sodium accumulation of two maize hybrids. Functional Plant Biology, 21: 675-692.

38. Cuartero J., Boların M. C., Asins M. J., Moreno V. 2006. Increasing salt tolerance in the tomato. Journal of Experimental Botany, 57: 1045-1058 http://dx.doi.org/10.1093/jxb/erj102.

39. Cuin T. A., Zhou M., Parsons D., Shabala S. 2011. Genetic behavior of physiological traits conferring cytosolic $\mathrm{K}^{+}$/ $\mathrm{Na}^{+}$homeostasis in wheat. Plant Biologv. 14: 438-446 http://dx.doi.org/10.1111/j.1438-8677.2011.00526.x.

40. Dawood M. G., Magdi T., Abdel H., Schmidhalter U. 2014. Potassium fertiliser enhances the salt-tolerance of common bean (Phaseolus vulgaris L.). Journal of Horticultural Science and Biotechnology. 89 (2): 185-192 http://dx.doi.org/10.1080/14620316.2014.11513067.

41. Demidchik V., Cuin T. A., Svistunenko D., Smith S. J., Miller A. J., Shabala S., Sokolik A., Yurin V. 2010. Arabidopsis root $\mathrm{K}^{+}$efflux conductance activated by hydroxyl radicals: single-channel properties, genetic basis and involvement in stress-induced cell death. Journal of Cell Science, 123: 1468-1479 http://dx.doi.org/10.1242/jcs.064352.

42. Dogan M., Tipirdamaz R., Demir Y. 2010. Salt resistance of tomato species grown in sand culture. Plant, Soil and Environment, 56: 499-507.

43. Engels C., Marschner H. 1992. Adaptation of potassium translocation into the shoot of maize (Zea mays) to shoot demand: evidence for xylem loading as a regulating step. Physiologia Plantarum, 86 (2): 263-268 http://dx.doi.org/10.1034/j.1399-3054.1992.860211.x.

44. Evelin H., Kapoor R., Giri B. 2009. Arbuscular mycorrhizal fungi in alleviation of salt stress: a review. Annals of Botany. 104: 1263-1280 http://dx.doi.org/10.1093/aob/mcp251.

45. Ferreira R. G., Tovora F. J. A. F., Hernandez F. F. F. 2001. Dry matter partitioning and mineral composition of roots, stems and leaves of guava grown under salt stress conditions. Pesquisa Agropecuária Brasileira. 36: 79-88 http://dx.doi.org/10.1590/S0100-204X2001000100010.

46. Flowers T. J., Galal H. K., Bromham L. 2010. Evolution of halophytes: multiple origins of salt tolerance in land plants. Functional Plant Biology, 37: 604-612 http://dx.doi.org/10.1071/FP09269.

47. Freitas J. B. S., Chagas R. M., Almeida I. M. R., Cavalcanti F. R., Silveira J. A. G. 2001. Expression of physiological traits related to salt tolerance in two contrasting cowpea cultivars. Documentos Embrapa Meio Norte, 56: 115-118.

48. Fukuda A., Nakamura A., Tagiri A., Tanaka H., Miyao A., Hirochika H., Tanaka Y. 2004. Function, intracellular localization and the importance in salt tolerance of a vacuolar $\mathrm{Na}^{+} / \mathrm{H}^{+}$antiporter from rice. Plant and Cell Physiology, 45 (2): 146-159 http://dx.doi.org/10.1093/pcp/pch014.

49. Gadallah M. A. A. 1999. Effects of proline and glycinebetaine on Vicia faba responses to salt stress. Biologia Plantarum. 42: 249-257 http://dx.doi.org/10.1023/A:1002164719609.

50. Garthwaite A. J., von Bothmer R., Colmer T. D. 2005. Salt tolerance in wild Hordeum species is associated with 
restricted entry of $\mathrm{Na}^{+}$and $\mathrm{Cl}^{-}$into the shoots. Journal of Experimental Botany, 56: 2365-2378

http://dx.doi.org/10.1093/jxb/eri229.

51. Ghoulam C., Foursy A., Fares K. 2002. Effects of salt stress on growth, inorganic ions and proline accumulation in relation to osmotic adjustment in five sugar beet cultivars. Environmental and Experimental Botany, 47 (1): 39-50 http://dx.doi.org/10.1016/S0098-8472(01)00109-5.

52. Gopal R., Dube B. K. 2003. Influence of variable potassium on barley metabolism. Annals of Agricultural Research, 24: 73-77.

53. Grattan S. R., Grieve C. M. 1999. Salinity-mineral nutrient relations in horticultural crops. Scientia Horticulturae, 78 (1-4): 127-157.

54. Hasegawa P. M., Bressan R. A., Zhu J. K., Bohnert H. J. 2000. Plant cellular and molecular response to high salinity. Annual Review of Plant Physiology and Molecular Biology, 51: 463-499

http://dx.doi.org/10.1146/annurev.arplant.51.1.463.

55. Hayat S., Ahmad A. 2003. Soaking seeds of Lens culinaris with 28-homobrasinolid increased nitrate reductase activity. Annals of Applied Biology, 143: 121-124 http://dx.doi.org/10.1111/j.1744-7348.2003.tb00276.x.

56. Hernandez J. A., Olmos E., Corpas F. J., Sevilla F., Del Rio L.A. 1995. Salt-induced oxidative stress in chloroplasts of pea plants. Plant Science, 105: 151-167 http://dx.doi.org/10.1016/0168-9452(94)04047-8.

57. Hu Y., Schmidhalter U. 2005. Drought and salinity: a comparison of their effects on mineral nutrition of plants. Journal of Plant Nutrition and Soil Science, 168: 541-549 http://dx.doi.org/10.1002/jpln.200420516.

58. Jamil M., Lee K. B., Jung K. Y., Lee D. B., Han M. S., Rha E. S. 2007. Salt stress inhibits germination and early seedling growth in cabbage (Brassica oleracea L.). Pakistan Journal of Biological Science, 10: 910-914 http://dx.doi.org/10.3923/pjbs.2007.910.914.

59. Kabir M. E., Karim M. A., Azad M. A. K. 2004. Effect of potassium in salinity tolerance of mungbean (Vigna radiate L.). Journal of Biological Science, 4: 103-111 http://dx.doi.org/10.3923/jbs.2004.103.110.

60. Karimi G., Ghorbanli M., Heidari H., Khavarinejad R. A., Assareh M. H. 2005. The effects of $\mathrm{NaCl}$ on growth, water relations, osmolytes and ion content in Kochia prostrate. Biologia Plantarum, 49: 301-304 http://dx.doi.org/10.1007/s10535-005-1304-y.

61. Khan M. A., Ungar I. A., Showalter A. M., Dewald H. D. 1998. NaCl-induced accumulation of glycinebetaine in four subtropical halophytes from Pakistan. Physiologia Plantarum, 102 (4): 487-492 http://dx.doi.org/10.1034/j.1399-3054.1998.1020402.x.

62. Kholova J., Sairam R. K., Meena R. C. 2010. Osmolytes and metal ions accumulation, oxidative stress and antioxidant enzymes activity as determinants of salinity stress tolerance in maize genotypes. Acta Physiologiae Plantarum, 32 (3): 477-486

http://dx.doi.org/10.1007/s11738-009-0424-y.

63. Kumar D. 1984. The value of certain plant parameters as an index for salt tolerance in Indian mustard (Brassica iuncea L.). Plant and Soil, 79: 261-272 http://dx.doi.org/10.1007/BF02182349.

64. Liang T. B., Wang Z. L., Wang R. J., Liu L. L., Shi C. Y. 2007. Effects of potassium humate on ginger root growth and its active oxygen metabolism. Ying Yong Sheng Tai Xue Bao, 18 (4): 813-817 (in Chinese).

65. Lindsay M. P., Lagudah E. S., Hare R. A., Munns R. 2004. A locus for sodium exclusion (Nax1), a trait for salt tolerance, mapped in durum wheat. Functional Plant Biology, 31: 1105-1114 http://dx.doi.org/10.1071/FP04111.
66. Mahmood K. 2011. Salinity tolerance in barley (Hordeum vulgare $\mathrm{L}$.): effects of varying $\mathrm{NaCl}, \mathrm{K}^{+} / \mathrm{Na}^{+}$and $\mathrm{NaHCO}_{3}$ levels on cultivars differing in tolerance. Pakistan Journal of Botany, 43: 1651-1654.

67. Mansour M. M. F. 2000. Nitrogen containing compounds and adaptation of plants to salinity stress. Biologia Plantarum, 43: 491-500 http://dx.doi.org/10.1023/A:1002873531707.

68. Marschner H., Cakmak I. 1989. High light-intensity enhances chlorosis and necrosis in leaves of zinc, potassium, and magnesium deficient bean (Phaseolus vulgaris) plants. Journal of Plant Physiology, 134: 308-315 http://dx.doi.org/10.1016/S0176-1617(89)80248-2.

69. Meloni D. A., Gulotta M. R., Martinez C. A., Oliva M. A. 2004. The effect of salt stress on growth, nitrate reduction and proline and glycinebetain accumulation in Prosopis alba. Journal of Plant Physiology, 16: 39-46.

70. Mengel K., Kirkby E. A. 2001. Principles of plant nutrition ( $5^{\text {th }}$ ed.) http://dx.doi.org/10.1007/978-94-010-1009-2.

71. Mittler R. 2002. Oxidative stress, antioxidants and stress tolerance. Trends in Plant Science. 7 (9): 405-410 http://dx.doi.org/10.1016/S1360-1385(02)02312-9.

72. Moons A., Bauw G., Prinsen E., Montagu M. V., Van der Straeten D. 1995. Molecular and physiological responses to abscisic acid and salts in roots of salt-sensitive and salt-tolerant Indica rice varieties. Plant Physiology, 107 (1): 177-186 http://dx.doi.org/10.1104/pp.107.1.177.

73. Munns R. 1993. Physiological process limiting growth in saline soil: some dogmas and hypotheses. Plant, Cell and Environment, 16: 15-24 http://dx.doi.org/10.1111/j.1365-3040.1993.tb00840.x.

74. Munns R. 2002. Comparative physiology of salt and water stress. Plant. Cell and Environment, 25 (2): 239-250 http://dx.doi.org/10.1046/j.0016-8025.2001.00808.x.

75. Munns R. 2005. Genes and salt tolerance: bringing them together. New Phytologist, 167: 645-663 http://dx.doi.org/10.1111/j.1469-8137.2005.01487.x.

76. Munns R., Tester M. 2008. Mechanisms of salinity tolerance. Annual Review of Plant Biology, 59: 651-681 http://dx.doi.org/10.1146/annurev.arplant.59.032607.092911.

77. Munns R., Hare A., James R. A., Rebetzke G. J. 2000. Genetic variation for improving the salt tolerance of durum wheat. Australian Journal of Agriculture Research, 51: 69-74 http://dx.doi.org/10.1071/AR99057.

78. Nabati J., Kafi M., Nezami A., Moghaddam P. R., Masoumi A., Mehrjerdi M. Z. 2011. Effect of salinity on biomass production and activities of some key enzymatic antioxidants in burning bush (Kochia scoparia). Pakistan Journal of Botany, 43: 539-548.

79. Nandwal A. S., Godara M., Kamboj D. V., Kundu B. S., Mann A., Kumar B., Sharma S. K. 2000. Nodule functioning in trifoliate and pentafoliate mungbean genotypes as influenced by salinity. Biologia Plantarum, 43: $459-462$ http://dx.doi.org/10.1023/A:1026704107525.

80. Netondo G. W., Onyango J. C., Beck E. 2004. Sorghum and salinity. II. Gas exchange and chlorophyll fluorescence of sorghum under salt stress. Crop Science, 44: 806-811 http://dx.doi.org/10.2135/cropsci2004.0806.

81. Noaman M. N. 2004. Effect of potassium and nitrogen fertilizers on the growth and biomass of some halophytes grown under high level of salinity. Journal of Agronomy, 3: $25-30$ http://dx.doi.org/10.3923/ja.2004.25.30.

82. Parida A. K., Das A. B. 2005. Salt tolerance and salinity effects on plants. Ecotoxicology and Environment Safety, 60: $324-349$ http://dx.doi.org/10.1016/j.ecoenv.2004.06.010. 
83. Perera L. K. R. R., Mansfield T. A., Malloch A. J. C. 1994. Stomatal responses to sodium ions in Aster tripolium: a new hypothesis to explain salinity regulation in above ground tissues. Plant, Cell and Environment, 17: 335-340 http://dx.doi.org/10.1111/j.1365-3040.1994.tb00300.x.

84. Pitman M. G., Lauchli A. 2002. A global impact of salinity and agricultural ecosystems. Lauchli A., Luttge V. (eds). Salinity: Environment - Plants - Molecules. Dordrecht, Netherlands, p. 3-20.

85. Pitzschke A., Forzani C., Hirt H. 2006. Reactive oxygen species signaling in plants. Plant Signaling and Behavior, 8: $1757-1764$ http://dx.doi.org/10.1089/ars.2006.8.1757.

86. Qasim M. 2000. Physiological and biochemical studies in a potential oilseed crop canola (Brassica napus L.) under salinity $(\mathrm{NaCl})$ stress. Ph. D thesis, Department of Botany, University of Agriculture, Faisalabad, Pakistan.

87. Qasim M., Ashraf M. 2006. Time course of ion accumulation and its relationship with the salt tolerance of two genetically diverse lines of canola (Brassica napus L.). Pakistan Journal of Botany, 38: 663-672.

88. Qin J., Dong W. Y., He K. N., Yu Y., Tan G. D., Han L., Dong M., Zhang Y. Y., Zhang D., Li A. Z., Wang Z. L. 2010. $\mathrm{NaCl}$ salinity-induced changes in water status, ion contents and photosynthetic properties of Shepherdia argentea (Pursh) Nutt. seedlings. Plant, Soil and Environment, 56 (7): 325-332.

89. Rahnama A., James R. A., Poustini K., Munns R. 2010. Stomatal conductance as a screen for osmotic stress tolerance in durum wheat growing in saline soil. Functional Plant Biology, 37 (3): 255-263 http://dx.doi.org/10.1071/FP09148.

90. Rascio A., Russo M., Mazzucco L., Platani C., Nicastro G., Fonzo N. D. 2001. Enhanced osmotolerance of a wheat mutant selected for potassium accumulation. Plant Science, 160: 441-448

http://dx.doi.org/10.1016/S0168-9452(00)00404-0.

91. Raza S. H., Athar H. R., Ashraf M. 2006. Influence of exogenously applied glycinebetaine on the photosynthetic capacity of two differently adapted wheat cultivars under salt stress. Pakistan Journal of Botany, 38: 341-351.

92. Reddy A. R., Chaitanya K. V., Vivekanandan M. 2004. Drought-induced responses of photosynthesis and antioxidant metabolism in higher plants. Journal of Plant Physiology, 161 (11): 1189-1202

http://dx.doi.org/10.1016/j.jplph.2004.01.013.

93. Rivelli A. R., James R. A., Munns R., Condon A. G. 2002. Effect of salinity on water relations and growth of wheat genotypes with contrasting sodium uptake. Functional Plant Biology, 29: 1065-1074

http://dx.doi.org/10.1071/PP01154.

94. Sairam R. K., Deshmukh P. S., Saxena D. C. 1998. Role of antioxidant system in wheat genotypes tolerance to water stress. Biologia Plantarum, 41: 387-394 http://dx.doi.org/10.1023/A:1001898310321.

95. Sanjakkara U. R., Frehner M., Nosberger J. 2001. Influence of soil moisture and fertilizer potassium on the vegetative growth of mungbean (Vagna radiate L.) and cowpea (Vigna ungulculata L.). Journal of Agronomy Crop Science, 186: 73-81 http://dx.doi.org/10.1046/j.1439-037X.2001.00433.x.

96. Santa-Maria G. E., Epstein E. 2001. Potasium/sodium selectivity in wheat and the amphiploid cross wheat $x$ Lophophyrum elongatum. Plant Science, 160: 523-534 http://dx.doi.org/10.1016/S0168-9452(00)00419-2.

97. Serraj R., Drevon J.-J. 1998. Effects of salinity and nitrogen source on the growth and nitrogen fixation in alfalfa. Journal of Plant Nutrition, 21 (9): 1805-1818 http://dx.doi.org/10.1080/01904169809365525.
98. Shabala S. 2013. Learning from halophytes: physiological basis and strategies to improve abiotic stress tolerance in crops. Annals of Botany, 112: 1209-1221 http://dx.doi.org/10.1093/aob/mct205.

99. Shabala S., Cuin T. A. 2008. Potassium transport and plant salt tolerance. Physiologia Plantarum, 133 (4): 651-669 http://dx.doi.org/10.1111/j.1399-3054.2007.01008.x.

100. Shabala S., Demidchik V., Shabala L., Cuin T. A., Smith C. J., Miller A. J., Davies J. M., Newman I. A. 2006. Extracellular $\mathrm{Ca}^{2+}$ ameliorates $\mathrm{NaCl}$-induced $\mathrm{K}^{+}$loss from Arabidopsis root and leaf cells by controlling plasma membrane $\mathrm{K}^{+}$-permeable channels. Plant Physiology, 141 (4): $1653-1665$ http://dx.doi.org/10.1104/pp.106.082388.

101. Shabala S., Cuin T. A., Prismall L., Nemchinov L. G. 2007. Expression of animal CED-9 anti-apoptotic gene in tobacco modifies plasma membrane ion fluxes in response to salinity and oxidative stress. Planta, 227: 189-197 http://dx.doi.org/10.1007/s00425-007-0606-z.

102. Shalata A., Mittova V., Volokita M., Guy M., Tal M. 2001. Response of cultivated tomato and its wild salttolerant relative Lycopersicon pennellii to salt-dependent oxidative stress: the root antioxidative system. Physiologia Plantarum, 112 (4): 487-494 http://dx.doi.org/10.1034/j.1399-3054.2001.1120405.x.

103. Shannon M. C., Rhoades J. D., Draper J. H., Scardaci S. C., Spyres M. D. 1998. Assessment salt tolerance in rice cultivars in response to salinity problems in California. Crop Science, 38 (2): 394-398 http://dx.doi.org/10.2135/c ropsci1998.0011183X003800020021x.

104. Sharif M., Hussain S. 1993. Maize response of potassium fertilizer at Mardan, Sarhad. Journal of Agriculture, 9: 257-261.

105. Singh S. K., Sharma H. C., Goswami A. M., Datta S. P., Singh S. P. 2000. In vitro growth and leaf composition of grapevine cultivars as affected by sodium chloride. Biologia Plantarum, 43: 283-286 http://dx.doi.org/10.1023/A:1002720714781.

106. Smethurst C. F., Rix K., Garnett T., Auricht G., Bayart A., Lane P., Wilson S. J., Shabala S. 2008. Multiple traits associated with salt tolerance in lucerne: revealing the underlying cellular mechanisms. Functional Plant Biology, 35: $640-650$ http://dx.doi.org/10.1071/FP08030.

107. Soleimanzadeh H. D., Habibi M. R., Ardakani F., Paknejad Rejali F. 2010. Effect of potassium levels on antioxidant enzymes and malondialdehyde content under drought stress in sunflower (Helianthus annuus L.). American Journal of Agriculture and Biological Science, 5: 56-61 http://dx.doi.org/10.3844/ajabssp.2010.56.61.

108. Soussi M., Santamaria M., Ocana A., Lluch C. 2001. Effects of salinity on protein and lipopolysaccharide pattern in a salt-tolerant strain of Mesorhizobium ciceri. Journal of Applied Microbiology, 90: 476-481 http://dx.doi.org/10.1046/j.1365-2672.2001.01269.x.

109. Staal M., Maathuis F. J. M., Elzenga J. T. M., Overbeek J. H. M., Prins H. B. A. 1991. $\mathrm{Na}^{+} / \mathrm{H}^{+}$antiport activity in tonoplast vesicles from roots of the salt-tolerant Plantago maritima and the salt-sensitive Plantago media. Physiologia Plantarum, 82 (2): 179-184 http://dx.doi.org/10.1111/j.1399-3054.1991.tb00078.x.

110. Suelter C. H. 1985. Enzymes activated by monovalent cations. Science, 168: 789-795 http://dx.doi.org/10.1126/science.168.3933.789.

111. Sun J. K., Li T., Xia J. B., Tian J. Y., Lu Z. H., Wang R. T. 2011. Influence of salt stress on ecophysiological parameters of Periploca sepium Bunge. Plant, Soil and Environment, 57: 139-144. 
112. Ulfat M., Athar H. R., Ashraf M., Akram N. A., Jamil A. 2007. Appraisal of physiological and biochemical selection criteria for evaluation of salt tolerance in canola (Brassica napus L.). Pakistan Journal of Botany, 39: 1593-1608.

113. Unno H., Maeda Y., Yamamoto S., Okamoto M., Takenaga H. 2002. Relationships between salt tolerance and $\mathrm{Ca}^{2+}$ retention among plant species. Journal of Soil Science and Plant Nutrition, 73: 715-718.

114. Wenxue W., Bilsborrow P. E., Hooley D. A., Fincham E., Forster B. P. 2003. Salinity induced difference in growth, ion distribution and partitioning in barley between the cultivar Maythorpe and its derived mutant Golden Promise. Plant and Soil, 250: 183-191 http://dx.doi.org/10.1023/A:1022832107999.

115. White P. J., Broadley M. R. 2001. Chloride in soils and its uptake and movement within the plant. Annals of Botany, 88: 967-988 http://dx.doi.org/10.1006/anbo.2001.1540.

116. Yeo R. R., Flowers T. J. 1983. Varietal differences in the toxicity of sodium ions in rice leaves. Physiologia Plantarum, 59 (2): 189-195

http://dx.doi.org/10.1111/j.1399-3054.1983.tb00756.x.
117. Zhang H.-X., Blumwald E. 2001. Transgenic salt-tolerant tomato plants accumulate salt in foliage but not in fruit. Nature Biotechnology, 19: 765-768 http://dx.doi.org/10.1038/90824.

118. Zhang K., Wu W., Wang X. F. 2000. Corn response to potash on a Gongzhuling black soil, Jilin Province. Better Crops International, 14 (1): 10-11.

119. Zheng Y., Jia A., Ning T., Xu J., Li Z., Jaing G. 2008. Potassium nitrate application alleviates sodium chloride stress in winter wheat cultivars differing in salt tolerance. Journal of Plant Physiology, 165 (14): 1455-1465 http://dx.doi.org/10.1016/j.jplph.2008.01.001.

120. Zhu J.-K. 2001. Plant salt tolerance: regulatory pathway, genetic improvement and model systems. Trends in Plant Science, 6 (2): 66-71 http://dx.doi.org/10.1016/S1360-1385(00)01838-0.

121. Zhu J.-K., Liu J., Xiong L. 1998. Genetic analysis of salt tolerance in Arabidopsis: evidence for a critical role of potassium nutrition. The Plant Cell, 10 (7): 1181-1191 http://dx.doi.org/10.1105/tpc.10.7.1181.

ISSN 1392-3196 / e-ISSN 2335-8947

Zemdirbyste-Agriculture, vol. 103, No. 2 (2016), p. 229-238

DOI $10.13080 /$ z-a.2016.103.030

\title{
Druskos sukelto streso pasireiškimas augalams, tolerancijos druskingumui mechanizmas ir kalio įtaka mažinant druskos sukeltą stresą: apžvalga
}

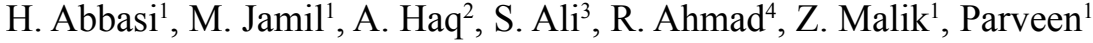 \\ ${ }^{1}$ Islamo universiteto žemès ūkio ir aplinkos mokslų kolegija, Pakistanas \\ ${ }^{2}$ Pakistano žemės ūkio universiteto Dirvožemio ir aplinkos mokslų institutas \\ ${ }^{3}$ Pakistano vyriausybès universiteto kolegija \\ ${ }^{4}$ COMSATS informacinių technologijų institutas, Pakistanas
}

\section{Santrauka}

Druskingumas yra žemès ūkio ir aplinkos problema, ribojanti augalų augimą bei vystymąsi sausringuose ir pusiau sausringuose pasaulio regionuose ir tampanti susirūpinimą keliančiu reiškiniu. Veikiami druskos streso augalai gali patirti osmosinį stresą, jonų toksiškumą ir mitybinį disbalansą, dèl to susidaro reaktyvios deguonies formos. Augalų geba detoksikuoti radikalus esant druskos stresui yra būtina sąlyga, nulemta ịvairių morfofiziologinių ir biocheminių veiksnių, pavyzdžiui, pirminio druskos patekimo i šaknis, tarpląstelinio pasidalijimo, osmoprotektorių (cukru, aminorūgščių, prolino ir antioksidacinès sistemos gradacijos) sintezès, dèl kurios palaikoma jonu homeostazè. Straipsnyje apibūdinama augalų reakcija ị druskos sukeltą stresą išryškinant fiziologinius ir biocheminius tolerancijos druskai mechanizmus, kurie galètu padèti ịvertinti druskos streso ekologinę svarbą tarpdisciplininiuose tyrimuose. Be to, kalio, kuris gerina augalų morfologines, fiziologines ir biochemines savybes, naudojimas augalams padeda susidoroti su žalingu druskingumo poveikiu.

Reikšminiai žodžiai: druskingumas, kalis, tolerancijos mechanizmas.

Please use the following format when citing the article:

H. Abbasi, M. Jamil, A. Haq, S Ali, R. Ahmad, Z. Malik, Parveen. 2016. Potassium regulation of ionic relations and redox status of salt affected plants: a review. Zemdirbyste-Agriculture, 103 (2): 229-238 DOI 10.13080/z-a.2016.103.030 